\title{
PENGARUH LIKUIDITAS, PROFITABILITAS DAN UKURAN PERUSAHAAN TERHADAP PERINGKAT OBLIGASI PADA INDUSTRI PERBANKAN YANG TERDAFTAR DI BURSA EFEK INDONESIA
}

\author{
Siti Hailatul Fikriyah \\ Universitas Pamulang \\ hailafikri@gmail.com
}

\begin{abstract}
Bond rating is one of the most important indicator about a company's credit quality. The objective of this research is to know how the liquidity, profitability, and size could influence to the bonds rating. This research use listed on Bursa Efek Indonesia. The samples of this research consist of 15 banks are listed in PT Pefindo from 2009-2012. Research method that used is descriptive analysis, with searching data through library, Financial statement from Bursa Efek Indonesia, and ICMD (Indonesian Capital Market Directory). The techniques of the test of the data be processed by using SPSS (Statistical Product and Service Solution) for windows release 20.00. Multinominal Logistic Regression Analysis with link function was used to the test the hypothesis. Therefore, the conclusion of this research has shown that the variable of liquidity and profitability, not significantly influence the bond rating. Meanwhile variable size significantly influence the bond rating
\end{abstract}

Keywords: liquidity, profitability, size, bond rating, PT. Pefindo, multinominal logistic regression.

\begin{abstract}
Abstrak
Peringkat obligasi adalah salah satu indikator mengenai kualitas kredit perusahaan. Objek dari penelitian ini adalah untuk mengetahui bagaimana likuiditas, profitabilitas, dan size dapat mempengaruhi peringkat obligasi. Penelitian ini menggunakan data keuangan yang diterbitkan di Bursa Efek Indonesia. Sampel dari penelitian ini terdiri dari 15 bank yang menerbitkan obligasi di PT Pefindo sejak tahun 2009 - 2012. Metode penelitian yang digunakan adalah analisis deskriptif, dengan data yang bersumber dari perpustakaan, laporan keuangan dari Bursa Efek Indonesia, dan ICMD (Indonesian Capital Market Directory). Teknik pengujian data diproses menggunakan dengan menggunakan program SPSS (Statistical Product and Service Solutions) versi 20.00. Analisis Regresi Logistik Multinominal yang berhubungan dengan fungsi digunakan untuk menguji hipotesis. Sehingga,
\end{abstract}


kesimpulan dari penelitian menunjukkan bahwa variabel likuiditas, dan profitabilitas tidak memiliki pengaruh yang signifikan terhadap peringkat obligasi. Sedangkan size memiliki pengaruh yang signifikan terhadap peringkat obligasi.

Kata kunci: likuiditas, profitabilitas, dan ukuran perusahaan, peringkat obligasi, PT. Pefindo, Regresi Logistik Multinominal.

\section{PENDAHULUAN}

Peringkat obligasi sangat penting karena mampu memberikan pernyataan informatif memberikan signal tentang probabilitas kegagalan utang suatu perusahaan (Ketz et al. 1990). Peringkat obligasi merupakan skala risiko, dari semua obligasi yang diperdagangkan. Skala tersebut menunjukkan tingkat keamanan suatu obligasi bagi investor. Keamanan ini ditunjukkan oleh kemampuan emiten (sebagai penerbit obligasi) dalam membayar bunga dan pelunasan pokok obligasi pada akhir masa jatuh temponya. Selain itu, dengan adanya pemeringkatan obligasi oleh agen pemeringkat maka investor dapat memperhitungkan return yang akan diperoleh dan risiko yang ditanggung.

Informasi peringkat obligasi bertujuan untuk menilai kualitas kredit dan kinerja dari perusahaan penerbit. Peringkat ini dinilai sangat penting bagi investor karena dapat dimanfaatkan untuk memutuskan apakah obligasi tersebut layak untuk dijadikan investasi serta mengetahui tingkat risikonya (Rahardjo, 2003). Investor obligasi memerlukan informasi yang dapat dijadikan acuan dalam mengkomunikasikan keputusan investasinya, sehingga informasi keuangan suatu entitas bisnis yang sangat berkualitas sangat diperlukan sebagai pertanggungjawaban atas pengelolaan dana yang ditanamkan.

Informasi yang terkandung dalam rating akan menunjukkan sejauh mana kemampuan suatu perusahaan untuk membayar kewajibannya atas dana yang diinvestasikan oleh investor. Perusahaan yang memiliki rating yang tinggi, biasanya lebih disukai oleh investor dibandingkan dengan perusahaan yang memiliki rating yang rendah. Permasalahan yang terjadi pada peringkat obligasi yang digunakan oleh investor kadang tidak sesuai dengan kondisi keuangan dan perusahaan yang sebenarnya, sehingga perlu mengetahui alat ukur-alat ukur apa yang menentukan menetukan perinkgat dalam perusahaan, sehingga peringkat ini dapat dijadikan sinyal untuk berinvestasi dalam obligasi.

Di Indonesia terdapat dua lembaga pemeringkat efek yaitu PT Kasnic Cresit Rating dan PT Pemeringkat Efek Indonesia (Pefindo). Jasa pemeringkatan dari PT Pefindo lebih banyak digunakan oleh perusahaan-perusahaan di Indonesia khususnya industri perbankan yang terdaftar di BEI. Aspek penilaian obligasi yang dilakukan PT Pefindo berdasarkan pada tiga hal, yaitu aspek bisnis, aspek industri dan aspek keuangan. Penelitian oleh Susilowati dan Sumarto (2010) tentang aspek keuangan yang mempengaruhi peringkat obligasi memberikan bukti bahwa rasio likuiditas dapat digunakan untuk menentukan peringkat obligasi, 
sedangkan rasio profitabilitas, size dan maturity tidak mampu digunakan untuk menentukan peringkat obligasi. Begitu juga dengan penelitian Raharja dan Sari (2008) yang menemukan bahwa rasio leverage, likuiditas, solvabilitas, dan profitabilitas dapat digunakan untuk menentukan peringkat oblgasi. Penelitian selanjutnya adalah Sejati (2010) yang menemukan bahwa variabel profitabilitas, likuiditas, dan reputasi auditor tidak berpengaruh terhadap penentuan peringkat obligasi.

Tujuan dari penelitian ini adalah untuk mengkaji pengaruh likuiditas, profitabilitas, dan size terhadap peringkat obligasi bank yang terdaftar di Bursa Efek Indonesia dan menerbitkan obligasi di PT. Pefindo periode tahun 2009-2012.

\section{KAJIAN PUSTAKA DAN HIPOTESIS}

\subsection{Teori Sinyal}

Menurut Maria Immaculta (2006), kualitas keputusan investor dipengaruhi oleh kualitas informasi yang diungkapkan perusahaan dalam laporan keuangan. Kualitas informasi tersebut bertujuan untuk mengurangi asimetri informasi yang timbul ketika manajer lebih mengetahui informasi internal dan prospek perusahaan di masa mendatang dibanding pihak eksternal perusahaan. Informasi yang berupa pemberian peringkat obligasi perusahaan yang dipublikasikan diharapkan dapat menjadi sinyal kondisi keuangan perusahaan tertentu dan menggambarkan kemungkinan yang terjadi terkait dengan utang yang dimiliki.

Teori sinyal juga dapat membantu pihak perusahaan (agen), pemilik (prinsipal), dan pihak luar perusahaan mengurangi asimetri informasi dengan menghasilkan kualitas atau integritas informasi laporan keuangan. Untuk memastikan pihak-pihak yang berkepentingan meyakini keandalan informasi keuangan yang disampaikan pihak perusahaan (agen), perlu mendapatkan opini dari pihak lain yang bebas memberikan pendapat tentang laporan keuangan (Jama'an, 2008).

\subsection{Teori Asimetri Informasi}

Asimetri informasi merupakan suatu keadaan dimana manajer memiliki akses informasi atas prospek perusahaan yang tidak dimiliki oleh pihak luar perusahaan. Manajer sebagai pengelola perusahaan lebih banyak mengetahui informasi internal dan prospek perusahaan di masa yang akan datang dibandingkan pemilik (pemegang saham). Oleh karena itu sebagai pengelola, manajer berkewajiban memberikan sinyal mengenai kondisi perusahaan kepada pemilik. Sinyal yang diberikan dapat dilakukan melalui pengungkapan informasi akuntansi seperti laporan keuangan.

yaitu: Adverse selection, yaitu bahwa para manajer serta orang-orang dalam lainnya biasanya mengetahui lebih banyak tentang keadaan dan prospek perusahaan dibandingkan investor pihak luar. Dan fakta yang mungkin dapat mempengaruhi keputusan yang akan diambil oleh pemegang saham tersebut tidak 
disampaikan informasinya kepada pemegang saham. Moral hazard, yaitu bahwa kegiatan yang dilakukan oleh seorang manajer tidak seluruhnya diketahui oleh pemegang saham maupun pemberi pinjaman. Sehingga manajer dapat melakukan tindakan diluar pengetahuan pemegang saham yang melanggar kontrak dan sebenarnya secara etika atau norma mungkin tidak layak dilakukan.

\subsection{Teori Keagenan}

Agency Theory mengimplikasikan adanya asimetri informasi antara manajer (agen) dengan pemilik (prinsipal). Masalah agensi telah menarik perhatian yang sangat besar dari para peneliti di bidang akuntansi keuangan (Fuad, 2005). Masalah agensi timbul karena adanya konflik kepentingan antara shareholder dan manajer, karena tidak bertemunya utilitas yang maksimal antara mereka.

Teori keagenan dapat dipandang sebagai suatu versi dari game theory (Mursalim, 2005), yang membuat suatu model kontraktual antara dua atau lebih orang (pihak), dimana salah satu pihak disebut agent dan pihak yang lain disebut principal. Prinsipal mendelegasikan pertanggungjawaban atas decision making kepada agen, hal ini dapat pula dikatakan bahwa prinsipal memberikan suatu amanah kepada agen untuk melaksanakan tugas tertentu sesuai dengan kontrak kerja yang telah disepakati. Wewenang dan tanggungjawab agen maupun prinsipal diatur dalam kontrak kerja atas persetujuan bersama.

\subsection{Teori Risiko}

Menurut Djohanputro (2008), manajemen risiko merupakan proses terstruktur dan sistematis dalam mengidentifikasi, mengukur, memetakan, mengembangkan alternatif penanganan resiko, dan memonitor dan mengendalikan penanganan resiko. Smith (1990) mendifinisikan manajemen resiko sebagai proses identifikasi, pengukuran, dan kontrol keuangan dari sebuah resiko yang mengancam aset dan penghasilan dari sebuah perusahaan atau proyek yang dapat menimbulkan kerusakan atau kerugian pada perusahaan tersebut.

Risiko dapat dikategorikan ke dalam dua bentuk: Risiko spekulatif (business risk). adalah suatu keadaan yang dihadapi perusahaan yang dapat memberikan keuntungan dan juga dapat memberikan kerugian. Risiko murni (pure risk) adalah sesuatu yang hanya dapat berakibat merugikan atau tidak terjadi apa-apa dan tidak mungkin menguntungkan.

\subsection{Likuiditas}

Analisis rasio likuiditas adalah analisis yang dilakukan terhadap kemampuan bank dalam memenuhi kewajiban-kewajiban jangka pendeknya atau kewajiban yang sudah jatuh tempo. Rasio likuiditas yang sering dipergunakan dalam menilai kinerja suatu bank adalah cash ratio, reserve requirement, loan to deposit ratio, loan to asset ratio, dan rasio kewajiban bersih call money (Dendawijaya, 2005).

Likuiditas diukur dengan rasio aktiva lancar dibagi dengan kewajiban lancar. Perusahaan yang memiliki likuiditas sehat paling tidak memiliki rasio lancar sebesar $100 \%$. Ukuran likuiditas perusahaan yang lebih menggambarkan 
tingkat likuiditas perusahaan ditunjukkan dengan rasio kas (kas terhadap kewajiban lancar). Rasio likuiditas antara lain terdiri dari:

a) Current Ratio: adalah membandingkan antara total aktiva lancar dengan kewajiban lancar (current assets/current liabilities). Current liabilities merupakan kewajiban pembayaran dalam 1 tahun atau siklus operasi yang normal dalam usaha.

b) Quick Ratio: adalah membandingkan antara aktiva lancar dikurangi persediaan dengan kewajiban lancar. Persediaan terdiri dari alat-alat kantor, bahan baku, persediaan barang dalam proses, dan persediaan barang jadi. Tujuan manajemen persediaan adalah mengadakan persediaan yang dibutuhkan untuk operasi yang berkelanjutan pada biaya yang minimum.

\subsection{Profitabilitas}

Brigham dan Houston (2006:107) menyatakan bahwa "rasio profitabilitas akan menunjukkan efek dari likuiditas, manajemen aktiva, dan utang pada hasil operasi". Rasio ini digunakan untuk mengetahui kemampuan perusahaan dalam menghasilkan laba atau seberapa efektif pengelolaan perusahaan oleh manajemen. Untuk dapat melangsungkan hidupnya, perusahaan harus berada dalam keadaan yang menguntungkan. Apabila perusahaan berada dalam kondisi yang tidak menguntungkan, maka akan sulit bagi perusahaan untuk memperoleh pinjaman dari kreditor maupun investasi dari pihak luar.

Rasio profitabilitas merupakan rasio untuk mengukur kemampuan perusahaan memperoleh laba dalam hubungannya dengan penjualan, total aktiva maupun modal sendiri (Agus Sartono, 2008). Profitabilitas digunakan untuk mengukur efektifitas manajemen berdasarkan hasil pengembalian yang dihasilkan dari pinjaman dan investasi. Faktor-faktor yang mempengaruhi profitabilitas bank dapat bersumber dari berbagai kinerja profitabilitas yang ditunjukkan beberapa indikator (Nasser dan Aryati, 2000).

\subsection{Size}

Ukuran perusahaan menggambarkan besar kecilnya suatu perusahaan yang ditunjukkan oleh total aktiva, jumlah penjualan, rata-rata total penjualan, dan ratarata total aktiva (Sigit dalam Hana Tiara, 2012:2). Penentuan perusahaan dalam penelitian ini didasarkan pada total asset perusahaan. Total aktiva dipilih sebagai proksi ukuran perusahaan dengan mempertimbangkan bahwa nilai aktiva relative lebih stabil dibandingkan nilai market capitalized dan penjualan (Wuryatiningsih dalam Istiningdiah, 2012:15).

Untuk melakukan pengukuran terhadap ukuran perusahaan Prasetyantoko (2008:257) mengemukakan bahwa: "Aset total dapat menggambarkan ukuran perusahaan, semakin besar aset biasanya perusahaan tersebut semakain besar." Selanjutnya, Yogiyanto (2007:282) menyatakan bahwa : "Ukuran aktiva digunakan untuk mengukur besarnya perusahaan, ukuran aktiva tersebut diukur sebagai logaritma dari total aktiva".

Sementara itu, untuk menghitung nilai total asset Asnawi (2005:274) mengemukakan bahwa: "Nilai total asset biasanya bernilai sangat besar 
dibandingkan dengan variabel keuangan lainnya, untuk itu variabel asset diperhalus menjadi log asset atau ln asset."

\subsection{Peringkat Obligasi}

Menurut Keown et al. (2004) obligasi adalah suatu jenis hutang atau surat kesanggupan bayar jangka panjang yang dikeluarkan oleh peminjam yang berjanji membayar ke pemegangnya dengan sejumlah bunga tiap tahun yang sudah ditentukan sebelumnya. Sementara menurut Fakhruddin dan Hadianto (2001) obligasi adalah surat berharga atau sertifikat yang berisi kontrak antara pemberi pinjaman (dalam hal ini investor) dengan yang diberi pinjaman (issuer). Jadi, surat obligasi adalah selembar kertas yang menyatakan kepada perusahaan yang menerbitkan surat obligasi.

Investasi obligasi merupakan bagian dari instrumen fixed income yang cukup menarik bagi calon investor yang ingin mendapatkan keuntungan tingkat suku bunga cukup kompetitif dibandingkan dengan deposito. Jenis suku bunga yang diberikan bisa berbentuk suku bunga tetap (fixed rate) dan suku bunga mengambang (floating rate). Periode jatuh tempo biasanya sekitar lima tahun. Pembayaran suku bunga kepada pemegang obligasi bisa dilakukan dengan periode triwulan atau semester. Penerbitan obligasi melalui mekanisme pasar modal serta tercatat di bursa. Untuk menerbitkan obligasi diperlukan pihak penjamin emisi yang mengatur dan memasarkan obligasi tersebut kepada calon investor publik. Proses pemberian peringkat obligasi juga diperlukan untuk memberikan informasi yang akurat kepada investor. Penerbitan obligasi biasanya ditawarkan pada harga at par atau nominal. Instrumen obligasi ini banyak diminati oleh perusahaan dalam rangka mendapatkan dana tambahan untuk kebutuhan perusahaan (Sapto Rahardjo, 2003).

Obligasi mempunyai karakterikstik umum yang tercantum pada obligasi tersebut. Adapun karakteristik umum yang tercantum pada sebuah obligasi hampir mirip dengan karakteristik pinjaman utang pada umumnya, yaitu meliputi:

1) Nilai penerbitan obligasi (jumlah pinjaman dana),

2) Jangka waktu obligasi,

3) Tingkat suku bunga,

4) Jadwal pembayaran suku bunga,

5) Jaminan

Kinerja sebuah obligasi ditentukan oleh beberapa faktor yang penting, diantaranya adalah besar kecilnya kupon atau tingkat suku bunga obligasi, time maturity, discounting rate atau expectation yield, nilai penebusan, jadwal pembayaran kupon, dan masih banyak faktor risiko lainnya. Risiko investasi obligasi juga sangat banyak macamnya serta memerlukan pemahaman yang mendalam mengenai berbagai jenis risiko tersebut.

Selain itu, informasi mengenai berbagai jenis obligasi juga harus didapatkan secara lebih mendetail. Obligasi sendiri terdiri dari berbagai macam klasifikasi. Ada obligasi yang dibedakan atas dasar jenis penerbitnya; apakah pihak swasta atau pemerintah, bisa dibedakan atas dasar tingkat suku bunganya, dibedakan atas 
dasar ada tidaknya jaminan, dibedakan atas dasar metode pelunasan dan banyak faktor pembeda lainnya.

Peringkat obligasi adalah salah satu indikator penting mengenai kualitas kredit perusahaan (Baker dan Mansi dalam Zuhrotun dan Baridwan, 2005), sedangkan menurut Galil (2003) peringkat adalah pendapat mengenai creditworthiness dari obligor mengenai sekuritas hutang tertentu. Peringkat obligasi harus diperhatikan oleh investor apabila investor akan membeli obligasi karena peringkat obligasi dapat menunjukkan risiko obligasi. Risiko obligasi terkait dengan kemampuan perusahaan untuk membayar pokok pinjaman dan bunga pada saat jatuh tempo.

Sebelum di tawarkan, obligasi harus diperingkatkan oleh suatu lembaga atau agen pemeringkat obligasi (Rating Agency). Agen pemeringkat obligasi adalah lembaga independen yang memberikan informasi pemeringkatan skala risiko, dimana salah satunya adalah sekuritas obligasi sebagai petunjuk sejauh mana keamanan suatu obligasi bagi investor. Keamanan tersebut ditunjukkan oleh kemampuan suatu perusahaan dalam membayar bunga dan melunasi pokok pinjaman. Sehingga pemodal bisa menggunakan jasa agen pemeringkat obligasi tersebut untuk mendapatkan informasi mengenai peringkat obligasi. Proses pemeringkatan ini dilakukan untuk menilai kinerja perusahaan, sehingga rating agency dapat menyatakan layak atau tidaknya obligasi tersebut diinvestasikan.

Peringkat obligasi yang diumumkan ke publik dapat mengurangi asimetri informasi antara perusahaan penerbit obligasi dan investor. Penerbit obligasi ingin mengurangi asimetri informasi mengenai creditworthiness sekuritas hutangnya, akan tetapi tidak ingin mengungkapkan informasi privat ke publik. Oleh karena itu, penerbit obligasi dapat menggunakan agen pemeringkat sebagai pemberi sertifikasi independen (Baridwan dan Zuhrotun, 2005). Peringkat obligasi diperbaharui secara regular untuk mencerminkan perubahan signifikan dari kinerja keuangan dan bisnis persusahaan. Perubahan peringkat memiliki pengaruh signifikan pada aktivitas investasi dan pendanaan masa depan perusahaan serta profil risiko dan kinerja masa depannya.

Tabel 2.1. Definisi Peringkat Obligasi PT Pefindo (sumber: www.pefindo.com)

\begin{tabular}{cl}
\hline Rating & \multicolumn{1}{c}{ Keterangan } \\
\hline idAAA & Peringkat tertinggi \\
& Kemampuan obligor yang superior \\
& Mampu memenuhi kewajiban jangka panjangnya \\
idAA & Sedikit di bawah peringkat tertinggi \\
& Kemampuan obligor sangat kuat \\
idA & Kemampuan obligor yang kuat \\
& Cukup peka terhadap perubahan yang merugikan \\
idBBB & Kemampuan obligor yang memadai \\
& $\begin{array}{l}\text { Kemampuan dapat diperlemah oleh perubahan yang merugikan } \\
\text { idBB }\end{array}$ \\
& Kemampuan obligor agak lemah \\
& Terpengaruh oleh perubahan lingkungan bisnis \& ekonomi
\end{tabular}


$\operatorname{idB}$

Perlindungan sangat lemah

Obligor masih memiliki kemampuan membayar kewajiban

Perubahan lingkungan dapat memperburuk kinerja pembayarannya

idCCC Obligor tidak mampu lagi memenuhi kewajibannya

Bergantung pada perubahan lingkungan eksternal

$\operatorname{idD}$

Obligasi ini macet

Emiten sudah berhenti usaha

Kerangka pikir ditunjukkan pada Gambar 1. yang menunjukkan pengaruh masing-masing variabel independen terhadap variabel dependennya. Dalam penelitian ini terdapat tiga variabel independen, yaitu Likuiditas, Profitabilitas, dan Size. Sedangkan untuk variabel dependennya adalah Peringkat Obligasi.

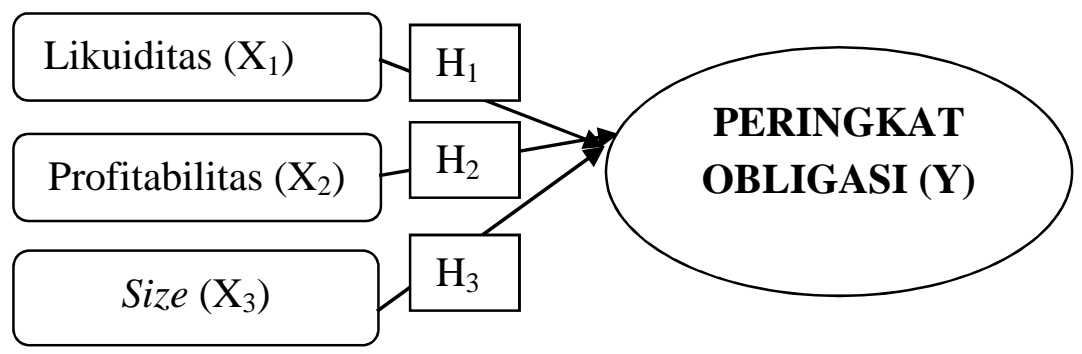

Gambar 1. Kerangka Pemikiran

\subsection{Hipotesis}

Peringkat obligasi perusahaan dari lembaga pemeringkat independen memberikan gambaran tentang kemampuan emiten untuk memenuhi kewajiban membayar bunga dan pokok secara tepat waktu dan dalam jumlah yang sesuai. Peringkat obligasi menggambarkan skala risiko dari obligasi yang diperdagangkan.

Peringkat obligasi memiliki arti penting bagi perusahaan dan investor. Pertama, karena peringkat obligasi merupakan indikator dari risiko gagal bayarnya, peringkat memiliki pengaruh langsung yang dapat diukur pada tingkat bunga obligasi dan biaya hutang perusahaan. Kedua, sebagian besar obligasi dibeli oleh investor institusional dan bukan individual, kebanyakan institusi dibatasi membeli efek yang layak investasi. Jadi, jika obligasi suatu perusahaan jatuh di bawah BBB, perusahaan tersebut akan sulit menjual obligasi baru karena banyak calon pembelinya yang tidak diperkenankan untuk membeli obligasi tersebut.

Beberapa penelitian terdahulu menurut Hickman (1958) dalam Yasa (2010) peringkat obligasi digunakan secara ekstensif dalam komunikasi investasi sebagai informasi pengukuran risiko obligasi. Pemeringkatan tersebut dilakukan untuk memberikan informasi kepada investor ataupun calon investor mengenai kemampuan dari penerbit obligasi untuk membayar bunga dan pokok utang berdasarkan analisis keuangan. Maka, peringkat obligasi dapat digunakan sebagai petunjuk seberapa aman suatu obligasi bagi investor, karena memberikan signal 
tentang probabilitas kegagalan pembayaran utang perusahaan dan kinerja dari emiten tersebut. Berdasarkan landasan teori dan penelitian terdahulu diatas maka hipotesis yang diajukan dalam penelitian ini sebagai berikut:

\section{Likuiditas}

Likuiditas mencerminkan tingkat kemampuan perusahaan untuk melunasi kewajiban jangka pendek. Carson \& Smith (1997 dalam Purwaningsih 2008) menemukan hubungan antara likuiditas dengan peringkat obligasi. Tingkat likuiditas yang tinggi menandakan pelunasan kewajiban jangka pendek yang baik. Apabila kemampuan melunasi utang jangka pendek baik maka setidaknya kemampuan perusahaan untuk melunasi utang jangka panjang juga semakin baik. Hal tersebut dikarenakan pengelolaan keuangan perusahaan yang baik, dengan terlunasinya kewajiban jangka pendek maka mengindikasikan bahwa kewajiban jangka panjang juga dapat terpenuhi.

$\mathrm{H}_{1}$ : Likuiditas berpengaruh terhadap peringkat obligasi

\section{Profitabilitas}

Profitabilitas merupakan tingkat kemampuan perusahaan untuk menghasilkan laba. Profitabilitas yang tinggi pada perusahaan mencerminkan kinerja yang baik. Penerbit obligasi yang memiliki profitabilitas tinggi akan berperingkat baik karena laba yang dihasilkan dapat digunakan untuk melunasi kewajiban. Hal tersebut didukung oleh pernyataan Burton (2003 dalam Susilowati \& Sumarto, 2010) bahwa tingkat profitabilitas yang tinggi menurunkan risiko insolvency (ketidakmampuan membayar utang).

$\mathrm{H}_{2}$ : Profitabilitas berpengaruh terhadap peringkat obligasi

\section{Size}

Ukuran perusahaan atau size dapat tercermin dari total assets, penjualan maupun ekuitas yang dimiliki suatu perusahaan. Menurut Elton dan Gruber (1995 dalam Devi, 2007) menyatakan bahwa perusahaan kecil lebih memiliki risiko yang besar dibandingkan dengan perusahaan besar. Aset yang dimiliki perusahaan besar relatif lebih besar jumlahnya sehingga dengan aset tersebut dapat digunakan untuk jaminan membayar obligasi. Oleh karena itu perusahaan yang besar diasumsikan memiliki kemampuan untuk melunasi kewajiban obligasi, sehingga peringkat obligasi menjadi lebih baik.

$\mathrm{H}_{3}$ : Size berpengaruh terhadap peringkat obligasi

\section{METODE PENELITIAN}

Penelitian ini menggunakan metode penelitian asosiatif kausal. Menurut Sugiyono (2008:56), desain asosiatif kausal berguna untuk menganalisis hubungan antara satu variabel dengan variabel lainnya atau bagaimana suatu variabel penelitian ini adalah penelitian untuk mengetahui pengaruh satu variabel atau lebih (variabel bebas) terhadap variabel tertentu (variabel terikat) dengan memerlukan pengujian hipotesis dengan uji statistik. Dalam hal ini untuk mengetahui pengaruh likuiditas, profitabilitas, dan size pada perusahaan sektor 
perbankan dengan pengujian statistik guna mengetahui apakah ketiga variabel tersebut mempunyai pengaruh yang signifikan terhadap peringkat obligasi.

Operasionalisasi variabel sebagai berikut:

a) Variabel Dependen

Variabel dependen dalam penelitian ini adalah peringkat obligasi. Variabel ini dilihat berdasarkan peringkat yang dikeluarkan oleh Pefindo (Pemeringkat Efek Indonesia) dengan menggunakan skala ordinal yang diukur berdasarkan kode $1-8$, seperti yang terlihat pada tabel 3.1. berikut.

Tabel 3.1. Kategorisasi Peringkat Obligasi

\begin{tabular}{|c|c|c|c|}
\hline Peringkat Obligasi & Skala & Peringkat Obligasi & Skala \\
\hline AAA & 8 & $\mathrm{BB}$ & 4 \\
\hline AA & 7 & B & 3 \\
\hline A & 6 & $\mathrm{CCC}$ & 2 \\
\hline $\mathrm{BBB}$ & 5 & $\mathrm{D}$ & 1 \\
\hline
\end{tabular}

Tabel 3.2. menunjukkan peringkat obligasi yang merupakan variabel dependen dalam penelitian ini dengan peringkat obligasi berikut:

Tabel 3.2. Peringkat Obligasi

\begin{tabular}{clcccc}
\hline \multirow{2}{*}{ NO. } & \multirow{2}{*}{ KODE } & \multicolumn{4}{c}{ PERINGKAT OBLIGASI TAHUN } \\
\cline { 3 - 6 } 1 & BABP & BBB & BBB & BBB & BBB \\
2 & BBKP & - & - & - & A \\
3 & BBNI & AA & AA & AA & - \\
4 & BBRI & AAA & AAA & AAA & AAA \\
5 & BBTN & AA & AA & AA & AA \\
6 & BDNM & AA & AA & AA & AA \\
7 & BJBR & A & AA & AA & AA \\
8 & BMRI & AAA & AAA & AAA & AAA \\
9 & BNGA & - & - & AAA & AAA \\
10 & BNII & - & - & AA & AAA \\
11 & BNLI & A & A & AA & AA \\
12 & BVIC & - & - & - & BBB \\
13 & NISP & AA & AA & AA & AA \\
14 & PNBN & AA & AA & AA & AA \\
15 & SDRA & - & - & BBB & BBB \\
\hline
\end{tabular}

Sumber : Data Sekunder Diolah 2015 
b) Variabel Independen

Variabel independen yang hendak diuji dalam penelitian ini ada lima, yaitu:

1) Likuiditas. Likuiditas dalam penelitian ini diproksikan melalui Current Ratio yang akan dihitung dengan membagi Current Asset dengan Current Liabilities.

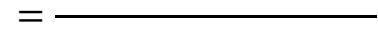

2) Profitabilitas. Profitabilitas dalam penelitian ini diproksikan melalui Return on Asset dimana dihitung dari Net Income dibagi dengan Total Asset.

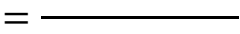

3) Size. Size atau ukuran perusahaan menunjukkan tingkat besar atau kecilnya suatu perusahaan yang dapat didasarkan pada total aktiva, penjualan, atau ekuitas. Proksi size yang digunakan dalam penelitian ini berdasarkan pada total aktiva karena lebih mencerminkan kekayaan perusahaan secara menyeluruh. Secara sistematis ukuran perusahaan (firm size) dirumuskan sebagai berikut:

$$
\text { Size }=\log \mathrm{TA}
$$

\subsection{Populasi dan Sampel Penelitian}

Definisi populasi menurut Sugiyono (2011:61) adalah wilayah generalisasi yang terdiri atas obyek/subjek yang mempunyai kuantitas dan karakteristik tertentu yang diterapkan oleh peneliti untuk dipelajari dan kemudian ditarik kesimpulannya. Sampel menurut Supranto (2008:23) adalah sebagian dari populasi. Dasar penarikan sampel dalam penelitian ini adalah sampel yang memenuhi kriteria yang ditetapkan untuk membantu tercapainya tujuan penelitian. Berdasarkan hal diatas, metode yang digunakan untuk pemilihan sampel dalam penelitian ini dilaksanakan dengan cara purposive sampling. Menurut Aritonang (2007:103) purposive sampling ini tergolong dalam teknik pemilihan sampel tak acak yang mana unsur populasi yang diambil menjadi sampel didasarkan pada tujuan penelitian dan tiap unsur populasi tidak memiliki peluang yang sama untuk dipilih. Adapun kriteria dalam pengambilan sampel adalah sebagai berikut:

1) Obligasi perbankan yang diperingkatkan oleh lembaga pemeringkat obligasi (PEFINDO) periode 2009-2012.

2) Obligasi perusahaan yang termasuk perusahaan perbankan yang terdaftar di Bursa Efek Indonesia tahun 2009 sampai dengan 2012.

3) Obligasi perusahaan perbankan tersebut memiliki periode laporan keuangan per 31 Desember dan dipublikasikan oleh BEI

4) Menggunakan mata uang Rupiah dalam penyajian laporan keuangan 


\subsection{Teknik Pengumpulan Data}

Teknik pengumpulan data adalah dengan menggunakan dokumentasi yaitu data yang diperoleh dari berbagai dokumen atau literatur yang berkaitan dengan masalah yang sedang diteliti. Data diperoleh dari media cetak, elektronik, maupun internet.

\subsection{Teknik Analisis Data}

\subsubsection{Multinominal Logistic Regression}

Multinominal Logistic Regression merupakan perluasan dari binary (dua kategori) Logistic Regression jika variabel dependen mempunyai kategori lebih dari dua. Dalam penelitian ini, model analisis yang dipergunakan adalah regresi dengan software Statistical Package for the Social Science (SPSS) versi 20 untuk mengetahui pengaruh masing-masing variabel yang diteliti terhadap peringkat obligasi.

Penelitian ini menguji pengaruh profitabilitas, likuiditas, leverage, size, dan reputasi auditor terhadap peringkat obligasi. Adapun model regresi multinominal logistik penelitian ini adalah:

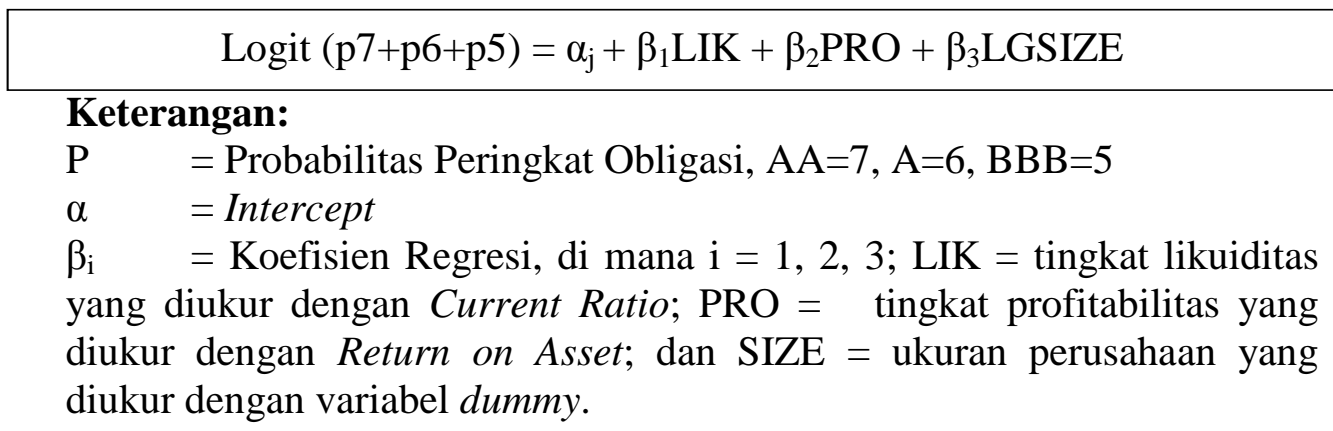

\subsubsection{Uji Hipotesis}

Tahapan dalam pengujian dengan menggunakan uji regresi logistik ordinal (ordinal logistic regression) dapat dijelaskan sebagai berikut:

1) Menilai Model Fit.

Adanya pengurangan nilai antara -2LL (-2 Log Likelihood) dengan nilai 2LL pada langkah berikutnya menunjukkan bahwa model yang dihipotesiskan fit dengan data. (Ghozali, 2006). Selain itu diadakan pengujian Goodness of fit dengan hipotesis yang sama dimana data dikatakan fit (hipotesis nol diterima) apabila tingkat signifikansi lebih besar dari 0,05 (5\%).

2) Koefisien Determinasi.

Pengukuran koefisien determinasi dilakukan untuk mengetahui persentase pengukuran variabel independen (prediktor) terhadap perubahan variabel dependen. Dari pengukuran ini akan diketahui seberapa besar persentase variabel dependen yang mampu dijelaskan oleh variabel independen dan sisa persentase yang dijelaskan oleh variabel-variabel lain di luar model penelitian.

3) Estimasi Parameter dan Interpretasinya. 
Estimasi parameter dari model regresi apakah hipotesis ditolak atau diterima dapat dilihat pada tampilan output variable in equation (Ghozali, 2009). Hal yang menjadi dasar pengambilan keputusan dalam menentukan suatu variabel signifikan atau tidak signifikan yang harus dibandingkan dengan tingkat signifikan yang telah ditetapkan yaitu 0,05 (Ghozali, 2009). Apabila suatu variabel memiliki signifikansi lebih besar dari 0,05 maka variabel tersebut tidak signifikan yang memiliki arti Ho diterima dan $\mathrm{Ha}$ ditolak. Tetapi apabila suatu variabel memiliki signifikansi lebih kecil dari 0,05 maka variabel tersebut signifikan yang berarti Ho ditolak dan $\mathrm{Ha}$ diterima.

\section{HASIL PENELITIAN DAN PEMBAHASAN}

\subsection{Identifikasi Sampel Penelitian}

Seleksi sampel mencakup sektor perbankan yang menerbitkan obligasi di PEFINDO, tetapi hanya sektor perbankan yang terdaftar di Bursa Efek Indonesia saja yang dipilih sebagai sampel dalam penelitian ini. Kriteria seleksi sampel mencakup pada perbankan yang terdaftar di Bursa Efek Indonesia dan menerbitkan obligasi di PEFINDO terhitung sejak tahun 2009-2012, yang mana data tersebut diperoleh dari www.pefindo.com, data laporan keuangan tahunan dari www.idx.co.id dan data keuangan ICMD (International Capital Market Directory). Adapun kriteria dalam pengambilan sampel adalah sebagai berikut:

1) Obligasi perusahaan yang diperingkatkan oleh lembaga pemeringkat obligasi (dalam penelitian ini mengambil data dari PEFINDO)

2) Obligasi perusahaan yang termasuk perusahaan perbankan yang terdaftar di BEI tahun 2009-2012

3) Obligasi perusahaan perbankan tersebut memiliki data laporan keuangan yang lengkap

4) Memiliki laporan auditor independen yang terdaftar di BEI sampai tahun 2012.

Berdasarkan kriteria yang ditentukan teridentifikasi sejumlah 15 bank dari total 32 bank yang menerbitkan obligasi di PEFINDO tahun 2009 - 2012. Ikhtisar seleksi sampel ditunjukkan pada tabel 5.1.

Tabel 5.1. Penyeleksian Sampel

\begin{tabular}{lc}
\hline \multicolumn{1}{c}{ Kriteria } & Jumlah \\
\hline Bank yang menerbitkan obligasi di PEFINDO 2009 -2012 & 32 \\
Bank yang tidak terdaftar di Bursa Efek Indoesia & $(17)$ \\
\hline Jumlah Sampel Penelitian & $\mathbf{1 5}$ \\
\hline
\end{tabular}

Sumber: Data Sekunder Diolah 2015

Dari 15 sampel bank yang teridentifikasi, terdapat 47 jumlah obligasi yang akan dijadikan sampel dalam penelitian ini. Adapun hasil dari penyeleksian tersebut ditunjukkan dalam Tabel 5.2. 
Tabel 5.2. Perusahaan yang Diteliti

\begin{tabular}{clc}
\hline No. & \multicolumn{1}{c}{ Nama Bank } & Jumlah Obligasi \\
\hline 1 & Bank ICB Bumiputera Tbk & 4 \\
2 & Bank Bukopin Tbk & 1 \\
3 & Bank Negara Indonesia & 3 \\
4 & Bank Rakyat Indonesia & 4 \\
5 & Bank Tabungan Negara Tbk & 4 \\
6 & Bank Danamon Indonesia Tbk & 4 \\
7 & Bank Jawa Barat & 4 \\
8 & Bank Mandiri Tbk & 4 \\
9 & Bank CIMB Niaga Tbk & 2 \\
10 & Bank Internasional Indonesia Tbk & 2 \\
11 & Bank Permata Tbk & 4 \\
12 & Bank Victoria & 1 \\
13 & Bank OCBC NISP & 4 \\
14 & Bank Pan Indonesia & 4 \\
15 & Bank Himpunan Saudara 1906 & 2 \\
\hline Jumlah & 47
\end{tabular}

\subsection{Hasil Penelitian}

\subsubsection{Analisis Regresi Logistik Multinominal}

Multinominal Logistic Regression merupakan perluasan dari binary (dua kategori) Logistic Regression jika variabel dependen mempunyai kategori lebih dari dua.

1) Model Fit

Pengujian ini menguji pengaruh dari masing-masing variabel independen yaitu likuiditas, profitabilitas, dan size, terhadap variabel dependennya yaitu peringkat obligasi. Analisis pertama yang dilakukan adalah menguji keseluruhan model (overall model fit). Pengujian ini dilakukan dengan membandingkan nilai antara -2 Log Likehood (-2LL) awal (intercept only) dengan -2 Log Likehood (-2LL) pada model final. Adanya pengurangan nilai antara -2LL (intercept only) dengan nilai -2LL pada model fit dengan data. (Ghazali, 2006).

Tabel Model Fitting Information

\begin{tabular}{|c|c|c|c|c|}
\hline \multirow{2}{*}{ Model } & $\begin{array}{c}\text { Model Fitting } \\
\text { Criteria }\end{array}$ & \multicolumn{3}{|c|}{ Likelihood Ratio Tests } \\
\cline { 2 - 5 } & -2 Log Likelihood & Chi-Square & Df & Sig. \\
\hline $\begin{array}{c}\text { Intercept Only } \\
\text { Final }\end{array}$ & $\begin{array}{c}109,883 \\
26,964\end{array}$ & 82,919 & 15 &, 000 \\
\hline
\end{tabular}

Link function: Logit

Sumber: Hasil Pengolahan SPSS 
Hal ini menunjukkan model dengan penambahan variabel lebih baik dalam memprediksi pengaruh peringkat obligasi, atau dengan kata lain menunjukkan bahwa model fit dengan data. Nilai signifikansi pada tabel di atas sebesar 0,000; yang berarti kurang dari 0,05 di mana hal tersebut berarti bahwa model fit dengan data.

Tabel Goodness-of-Fit

\begin{tabular}{|l|r|r|r|}
\hline & Chi-Square & Df & Sig. \\
\hline Pearson & 55,973 & 123 & 1,000 \\
Deviance & 26,964 & 123 & 1,000 \\
\hline
\end{tabular}

Link function: Logit

Sumber: Hasil Pengolahan SPSS

Sesuai dengan pendapat Ghazali (2006) yang menyatakan bahwa jika nilai goodness of fit sama dengan atau kurang dari 0,05 maka hipotesis nol ditolak, yang berarti model tidak sesuai karena tidak mampu memprediksi nilai observasinya. Tabel di atas menunjukkan hasil uji goodness of fit terlihat nilai signifikansi Pearson 1,000; lebih besar dari 0,05 yang berarti bahwa model sesuai untuk memprediksi nilai observasinya.

\section{2) Koefisien Determinasi}

Untuk mengetahui tingkat variabilitas variabel peringkat obligasi yang dapat dijelaskan oleh variabel likuiditas, profitabilitas, dan size, digunakan nilai Pseudo $R$ Square. Hasil pengujian koefisien determinasi dapat dilihat pada tabel berikut ini:

Tabel 5.5. Pseudo R-Square

\begin{tabular}{|l|r|}
\hline Cox and Snell &, 829 \\
Nagelkerke &, 917 \\
McFadden &, 755 \\
\hline
\end{tabular}

Link function: Logit

Sumber: Hasil Pengolahan SPSS

Hasil pengujian Pseudo $R$ Square pada tabel di atas menunjukkan nilai Nagelkerke $R$ Square sebesar 0,917. Hal ini berarti variabel dependen peringkat obligasi dapat dijelaskanoleh variabel independen berupa likuiditas, profitabilitas, dan size, sebesar $91,7 \%$ dan sisanya $8,3 \%$ dapat dijelaskan oleh variabel lain yang tidak terdapat dalam penelitian ini. Besarnya variabel peringkat obligasi yang mampu dijelaskan oleh variabel independen (likuiditas, profitabilitas, dan size) karena variabel independen dalam penelitian ini merupakan beberapa faktor yang mempengaruhi peringkat obligasi. 
Tabel 5.6. Likelihood Ratio Tests

\begin{tabular}{|l|r|r|r|r|}
\hline \multirow{2}{*}{ Effect } & \multicolumn{1}{|c|}{ Model Fitting Criteria } & \multicolumn{3}{|c|}{ Likelihood Ratio Tests } \\
\cline { 2 - 5 } & \begin{tabular}{|}
$\mid c$ Log Likelihood of Reduced \\
Model
\end{tabular} & Chi-Square & df & Sig. \\
\hline Intercept & $26,964^{\mathrm{a}}$ &, 000 & 0 & \\
LIK & $28,596^{\mathrm{b}}$ & 1,632 & 3 &, 652 \\
PRO & $30,422^{\mathrm{b}}$ & 3,457 & 3 &, 326 \\
LGSIZE & 58,986 & 32,021 & 3 &, 000 \\
\hline
\end{tabular}

Link function: Logit

Sumber: Hasil Pengolahan SPSS

Tabel Likelihood ratio test menunjukkan kontribusi setiap variabel independen terhadap variabel dependen. Variabel yang memberikan kontribusi pada model yaitu Size karena signifikan $(\mathrm{p}<0,05)$. Sedangkan variabel Likuiditas dan Profitabilitas tidak memberi kontribusi pada model karena tidak signifikan $(p>0,05)$.

\section{3) Estimasi Parameter dan Interpretasi}

Pengujian dilakukan dengan tingkat signifikansi sebesar 5\%. Jika nilai probabilitas lebih kecil dari 5\%, maka hipotesis diterima. Sedangkan jika nilai probabilitas lebih besar dari 5\%, maka hipotesis ditolak.

Tabel 5.7. Parameter Estimates

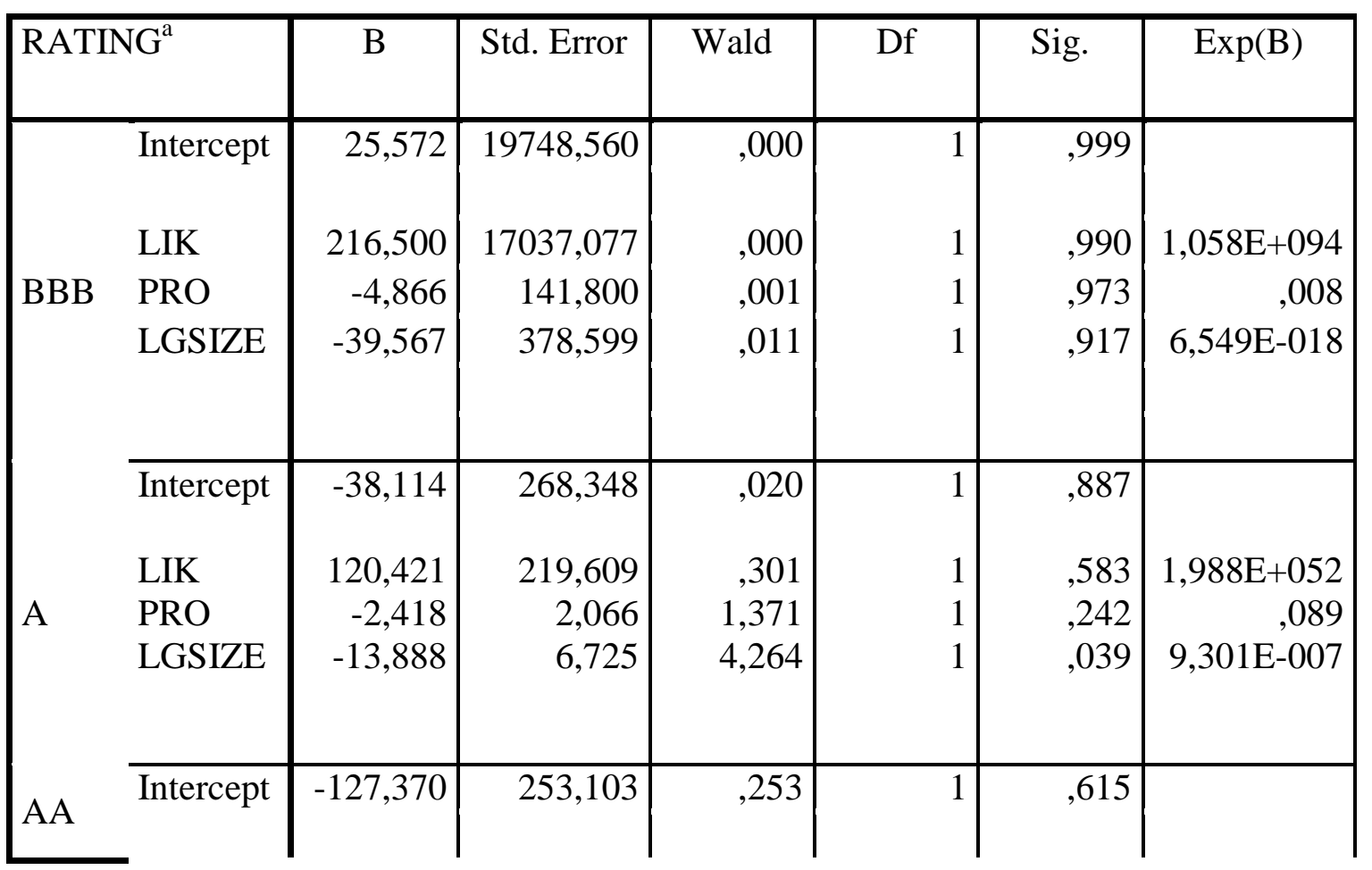




\subsection{Pengujian Hipotesis}

Penelitian ini menggunakan metode penelitian asosiatif kausal yang mengkaji pengaruh variabel independen terhadap variabel dependen. Pengujian hipotesis yang digunakan yaitu dengan menggunakan uji parameter estimasi, dengan hasil olah data sebagai berikut:

1) Pengaruh Likuiditas terhadap peringkat obligasi.

Variabel likuiditas dengan peringkat obligasi BBB (5) mempunyai koefisien negatif sebesar 216,500 dengan tingkat signifikansi 0,990 dan nilai statistik wald sebesar 0,000 serta nilai Odd ratio 1,058E+094. Hal ini menunjukkan tidak terdapat pengaruh yang signifikan antara likuiditas terhadap peringkat obligasi.

Variabel likuiditas dengan peringkat obligasi A (6) mempunyai koefisien negatif sebesar 120,421 dengan tingkat signifikansi 0,583 dan nilai statistik wald sebesar 0,301 serta nilai Odd ratio 1,988E+052. Hal ini menunjukkan tidak terdapat pengaruh yang signifikan antara likuiditas terhadap peringkat obligasi.

Variabel likuiditas dengan peringkat obligasi AA (7) mempunyai koefisien negatif sebesar 148,223 dengan tingkat signifikansi 0,480 dan nilai statistik wald sebesar 0,498 serta nilai Odd ratio 2,357E+064. Hal ini menunjukkan tidak terdapat pengaruh yang signifikan antara likuiditas terhadap peringkat obligasi.

2) Pengaruh Profitabilitas terhadap peringkat obligasi.

Variabel profitabilitas dengan peringkat obligasi BBB (5) mempunyai koefisien negatif sebesar $-4,866$ dengan tingkat signifikansi 0,973 dan nilai statistik wald sebesar 0,001 serta nilai Odd ratio 0,008. Hal ini menunjukkan tidak terdapat pengaruh yang signifikan antara profitabilitas terhadap peringkat obligasi.

Variabel profitabilitas dengan peringkat obligasi A (6) mempunyai koefisien negatif sebesar -2,418 dengan tingkat signifikansi 0,242 dan nilai statistik wald sebesar 1,371 serta nilai Odd ratio 0,089. Hal ini menunjukkan tidak terdapat pengaruh yang signifikan antara profitabilitas terhadap peringkat obligasi.

Variabel profitabilitas dengan peringkat obligasi AA (7) mempunyai koefisien negatif sebesar -3,459 dengan tingkat signifikansi 0,080 dan nilai statistik wald sebesar 3,061 serta nilai Odd ratio 0,031. Hal ini menunjukkan tidak terdapat pengaruh yang signifikan antara profitabilitas terhadap peringkat obligasi.

3) Pengaruh Size terhadap peringkat obligasi. 
Variabel size dengan peringkat obligasi BBB (5) mempunyai koefisien negatif sebesar -39,567 dengan tingkat signifikansi 0,917 dan nilai statistik wald sebesar 0,011 serta nilai Odd ratio 6,549E-018. Hal ini menunjukkan tidak terdapat pengaruh yang signifikan antara size terhadap peringkat obligasi.

Variabel size dengan peringkat obligasi A (6) mempunyai koefisien negatif sebesar $-13,888$ dengan tingkat signifikansi 0,039 dan nilai statistik wald sebesar 4,264 serta nilai Odd ratio 9,301E-007. Hal ini menunjukkan terdapat pengaruh yang signifikan antara size terhadap peringkat obligasi.

Variabel size dengan peringkat obligasi AA (7) mempunyai koefisien negatif sebesar -4,923 dengan tingkat signifikansi 0,097 dan nilai statistik wald sebesar 2,749 serta nilai Odd ratio 0,007. Hal ini menunjukkan tidak terdapat pengaruh yang signifikan antara size terhadap peringkat obligasi.

\subsection{Pembahasan}

Identifikasi sampel dan pengujian hipotesis memberikan penjelasan bagi analisis berikut ini. Hipotesis pertama $\left(\mathrm{H}_{1}\right)$ yaitu pengujian terhadap variabel likuiditas menunjukkan bahwa tidak terdapat pengaruh yang signifikan terhadap peringkat obligasi dengan tingkat signifikansi 0,990 untuk peringkat obligasi BBB (5); 0,583 untuk peringkat obligasi A (6); dan 0,480 untuk peringkat obligasi AA (7). Hasil penelitian ini sesuai dengan penelitian yang dilakukan oleh Sejati (2010), namun tidak sesuai dengan penelitian yang dilakukan oleh Sejati (2010), Susilowati dan Sumarto (2010), serta Almilia dan Devi (2007). Uji estimasi parameter ini sesuai dengan Likelihood ratio test dengan tingkat signifikansi 0,652 sehingga dapat dikatakan likuiditas tidak berpengaruh secara signifikan terhadap peringkat obligasi ( $\mathrm{p}>0,05)$.

Hipotesis kedua $\left(\mathrm{H}_{2}\right)$ bahwa pengujian terhadap variabel profitabilitas menunjukkan tidak terdapat pengaruh yang signifikan terhadap peringkat obligasi dengan tingkat signifikansi 0,973 untuk peringkat obligasi BBB (5); 0,242 untuk peringkat obligasi A (6); dan 0,080 untuk peringkat obligasi AA (7). Hasil penelitian ini tidak sesuai dengan penelitian yang dilakukan oleh Raharja dan Sari (2008) serta Magreta dan Poppy (2009), tetapi sesuai dengan penelitian yang dilakukan oleh Sejati (2010), Susilowati dan Sumarto (2010), serta Almilia dan Devi (2007). Uji estimasi parameter ini sesuai dengan Likelihood ratio test tingkat signifikansinya 0,326 sehingga dapat dikatakan profitabilitas tidak berpengaruh secara signifikan terhadap peringkat obligasi $(\mathrm{p}<0,05)$.

Hipotesis ketiga $\left(\mathrm{H}_{3}\right)$ yaitu pengujian terhadap variabel size menunjukkan bahwa tidak terdapat pengaruh yang signifikan terhadap penentuan peringkat obligasi dengan tingkat signifikansi 0,917 untuk peringkat obligasi BBB (5); dan 0,097 untuk peringkat obligasi AA (7). Hasil penelitian ini sesuai dengan penelitian yang dilakukan oleh Magreta dan Poppy (2009). Namun, untuk peringkat obligasi A (6), terdapat pengaruh yang signifikan antara variabel size terhadap peringkat obligasi dengan tingkat signifikansi 0,039. Sedangkan jika dilihat dari Likelihood ratio test tingkat signifikansinya 0,000 sehingga dapat dikatakan size berpengaruh secara signifikan terhadap peringkat obligasi $(\mathrm{p}<0,05)$. 
Selain dilakukan pengujian hipotesis, penulis juga melakukan uji regresi logistik multinominal dengan hasil olah data sebagai berikut:

$$
\begin{aligned}
& \text { Logit }(p 7+p 6+p 5)=\alpha_{j}+\beta_{1} \mathrm{LIK}+\beta_{2} \mathrm{PRO}+\beta_{3} \text { SIZE } \\
& \text { Logit p7 }=-127,370+148,223 \mathrm{LIK}+(-3,459) \text { PRO }+(-4,923) \text { LGSIZE } \\
& \text { Logit p6 }=-38,114+120,421 \mathrm{LIK}+(-2,418) \text { PRO }+(-13,888) \text { LGSIZE } \\
& \text { Logit p5 }=25,572+216,500 \mathrm{LIK}+(-4,866) \text { PRO + }(-39,567) \text { LGSIZE }
\end{aligned}
$$

\section{KESIMPULAN DAN SARAN}

Berdasarkan pada hasil pengujian dan keterbatasan tersebut di atas, maka dari pengolahan dan pengujian data dapat diperoleh kesimpulan sebagai berikut:

1) Tidak terdapat pengaruh yang signifikan antara likuiditas terhadap peringkat obligasi baik peringkat BBB (5), A (6), dan AA (7), baik secara Likelihood Ratio test maupun uji hipotesis.

2) Tidak terdapat pengaruh yang signifikan antara profitabilitas terhadap peringkat obligasi, baik peringkat BBB (5), A (6), dan AA (7), baik secara Likelihood Ratio test maupun uji hipotesis.

3) Berdasarkan uji hipotesis, tidak terdapat pengaruh yang signifikan antara size terhadap peringkat obligasi, untuk peringkat BBB (5) dan AA (7). Sedangkan untuk peringkat A (6), terdapat pengaruh yang signifikan antara size terhadap peringkat obligasi. Begitu juga berdasarkan Likelihood Ratio test, terdapat pengaruh yang signifikan antara size terhadap peringkat obligasi.

Berdasarkan hasil dari penelitian ini, terdapat beberapa saran yang ingin penulis paparkan. Pertama, berdasarkan Likelihood ratio test dan uji hipotesis, terdapat satu variabel yang berpengaruh secara signifikan yaitu size. Variabel Size di atas dapat dijadikan acuan dalam berinvestasi obligasi. Kedua, beberapa variabel dalam penelitian ini menggunakan proksi untuk mewakili perhitungan dari tiap variabel. Hendaknya penelitian selanjutnya perlu mempertimbangkan proksi yang digunakan untuk variabel independen. Ketiga, peringkat obligasi yang dilakukan tidak hanya yang dikeluarkan yang dikeluarkan oleh PEFINDO saja, namun dapat menggunakan peringkat obligasi yang dikeluarkan oleh lembaga pemeringkat lainnya, seperti PT. Kasnic Credit Rating Indonesia dan Standard and Poor's.

\section{DAFTAR PUSTAKA}

Adel, Jack Febrianci. (2004). Analisis Pengaruh Penurunan/Perolehan Peringkat Obligasi Perusahaan ke dalam Kategori Non-Investment Grade terhadap Praktik Manajemen Laba. Proceeding SNA VII. Bali.

Agoes, Suksrisno. (2012). Auditing Edisi 4 bukul. Jakarta: Salemba Empat. 
Almalia, L.S., \& Devi, V., (2007), Faktor-Faktor Yang Mempengaruhi Prediksi Peringkat Obligasi pada Perusahaan Manufaktur yang Terdaftar di Bursa Efek Jakarta, Proceeding SMART Membaca Jaman dalam Perspektif Manajemen, 2-3 November: 164-178.

Allen, Arthur C. (1994). The Effect of Large Firm Audits on Municipal Bond Rating Decisions. Journal Practice and Theory. Vol 13. Spring.

Altman, Edward I. (1968). "Financial Ratio, Discriminant Analysis and the Prediction of Corporate Bankruptcy". The Journal of Finance, pp 589-609.

Amrullah, K., (2007), Kemampuan Rasio Keuangan sebagai Alat untuk Memprediksi Peringkat Obligasi Perusahaan Manufaktur, Skripsi (Tidak Dipublikasikan), Universitas Negeri Semarang, Semarang.

Andry, Wydia. 2005. Analisis Faktor-Faktor yang Mempengaruhi Prediksi Peringkat Obligasi. Jurnal Buletin Ekonomi dan Moneter dan Perbankan. Vol.5, No.2 Nov 2003 : hal. 123-132.

Burton, B; Mike A; dan Hardwick, P. (2000). The Determinants of Credit Ratings in United Kingdom Insurance Industry. Working Paper. www.google.com.

Dendawijaya, Lukman. (2005). Manajemen Perbankan Edisi Kedua. Bogor: Ghalia Indonesia.

Elton, E.J.; Gruber, M.J.; Brown, S.J.; dan Goetzman, W.N. (2003). Modern Portfolio Theory and Investment Analysis. Sixth Edition, John Willey and Sons Inc., New York.

Fakhrudin, M. dan Sopian Hadianto. (2001). Perangkat dan Model Analisis Investasi di Pasar Modal. PT. Gramedia. Jakarta

Ghozali, I., (2007), Aplikasi Analisis Multivariate dengan Program SPSS, Cetakan IV, Badan Penerbit Universitas Diponegoro, Semarang.

Hadianto, Bram dan M. Sienly Veronica Wijaya. (2010). Prediksi Kebijakan Utang, Profitabilitas, Likuiditas, Ukuran Perusahaan, dan Status Perusahan terhadap Kemungkinan Penentuan Peringkat Obligasi: Studi Empirik Pada Perusahaan yang Menerbitkan Obligasi di Bursa Efek Indonesia. Jurnal Manajemen Teori dan Terapan. Tahun 3, No. 3, hal. 26.

Hanafi, M. (2004), Manajemen Keuangan, Edisi 2004/2005, BPFE-UGM, Yogyakarta.

Hartono, J. (2004). Metodologi Penelitian Bisnis: Salah Kaprah dan PengalamanPengalaman, Edisi 2004/2005, Cetakan Pertama, BPFE-UGM, Yogyakarta.

Haryanto. (2012). Ilmu Akuntansi. Kumpulan Teori Akuntansi Manajemen. http://www.ilmu akuntansi.web.id/pengertian-asimetri-informasi.com. (Diakses 15 Januari 2015).

Hasnawati, S., \& Dirja, R., (2008), Pengaruh Faktor Current Ratio, Debt to Equity, Return On Equity, Size, dan Maturity Terhadap Prediksi Peringkat Obligasi, Jurnal Manajemen, XII (3): 255-258.

Hermawan. (2006). Penelitian Bisnis: Paradigma Kuantitatif. Gramedia Widiasarana Indonesia, Jakarta. 
Ikhsan, Adhisyahfitri Evalina, M. Nur Yahya, dan Saidaturrahmi. (2012). Peringkat Obligasi dan Faktor yang Mempengaruhinya. Pekbis Jurnal, Vol.4, No.2, Juli 2012: 115-123. Fakultas Ekonomi Universitas Syiah Kuala.

Keown, Arthur J. (2004). Manajemen Keuangan: Prinsip-prinsip dan Aplikasi. Edisi 9,. PT. Indeks Kelompok Gramedia. Jakarta.

Ketz, John, Altman Edward, dan Maher. (1990). The Relationship of Asset Flow Measures to Bond Ratings. ABER Vol. 21. No. 2. Summer.

Konstantinos Liapis. (2011). The regulation framework for the banking sector: The EMU, European banks and rating agencies before and during the recent financial and debt crisis. International Journal of Disclosure and Governance Vol. 9, 4, 301-330.

Magreta dan Poppy Nurmayanti. (2009). Faktor-faktor yang Mempengaruhi Prediksi Peringkat Obligasi Ditinjau dari Faktor Akuntansi dan Non Akuntansi. Jurnal Bisnis dan Akuntansi Vol. 11. Hal. 143-154.

Manurung, Adler. H., Silitonga, D., dan Tobing, W.R.L., (2009), Hubungan Rasio-Rasio Keuangan dengan Rating Obligasi, PT Finansial Bisnis Informasi Jakarta, Artikel ini diakses melalui http://www.finansialbisnis.com/Data2/Riset/rating\%20paper\%20 \%20Desmon.pdf., pada tanggal 15 Desember 2009.

Mark, K; Peter, K; dan Teck-Kin, S. (2001). Combining Bond Rating Forecast Using Logit. The Financial Review, pp 75-96.

Miswanto dan Husnan, Suad.(1999). The Effect of Operating Leverage, Cyclicality and Firm Size on Business Risk. Gadjah Mada International Journal of Business. Vol. 1, No. 1. Hal. 29-43.

Nugrahadi, Indratno. (2012). Analisis Faktor-faktor yang Mempengaruhi Dividen Payout Ratio (Studi Empiris pada Perusahaan Sektor Perbankan yang Terdaftar di Bursa Efek Indonesia Periode 2006-2011). Thesis Magister Manajemen Keuangan Universitas Mercu Buana. Jakarta.

Pefindo. (2010). Metodologi Rating, Artikel ini diakses melalui http://new.pefindo.com/scrm_korporasi_index.php pada tanggal 5 Oktober 2010.

Pratomo, E.P., dan Nugraha, U. (2009). Reksa Dana: Solusi Perencanaan Investasi di Era Modern, Edisi Revisi Kedua. PT Gramedia. Jakarta.

Purwaningsih, A., (2008), Pemilihan Rasio Keuangan Terbaik Untuk Memprediksi Peringkat Obligasi. Jurnal Bisnis dan Ekonomi Kinerja. 12 (1): 85-99.

Raharja, dan Sari Maylia Pramono. (2008), Perbandingan Alat Analisis (Diskriminan dan Regresi Logistik Terhadap Peringkat Obligasi (PT Pefindo). Jurnal Maksi, 8 (1): 87-104.

Rahardjo, Sapto. 2003. Panduan Investasi Obligasi. PT Gramedia Pustaka Utama. Jakarta.

Restuti, Maria Immaculta. (2008). Pengaruh Pertumbuhan Perusahaan terhadap Peringkat dan Yield Obligasi. Skripsi (Tidak Diterbitkan). Universitas Pelita Harapan. 
Sartono, Agus. (2001). Pengaruh Aliran Kas Internal dan Kepemilikan Manajer dalam Perusahaan terhadap Pembelanjaan Modal: Managerial Hypotheses atau Pecking Order Hypotheses? Jurnal Ekonomi dan Bisnis Indonesia, 16 (1): 54-63.

Sartono, Agus. (2001). Manajemen Keuangan: Teori dan Aplikasi. Edisi 4. Yogyakarta: BPFE.

Sawir, Agnes. (2005). Analisis Kinerja Keuangan dan Perencanaan Keuangan. Gramedia Pustaka Utama. Jakarta.

Setyapurnama, Yudi Santara dan Vianey Norpratiwi. (2009), Pengaruh Corporate Governance Terhadap Peringkat Obligasi dan Yield Obligasi. Skripsi (Tidak Diterbitkan. Universitas Negeri Surakarta. Surakarta

Sugiarto, (2009), Struktur Modal, Struktur Kepemilikan Perusahaan, Permasalahan Keagenan, dan Informasi Asimetri, Edisi Pertama, Cetakan Pertama, Graha Ilmu. Yogyakarta.

Supranto, Johanes. (2008). Statistik: Teori dan Aplikasi. Edisi 7 buku 1. Erlangga. Jakarta.

Susilowati, Lucky dan Sumarto. (2010). Memprediksi Tingkat Obligasi Perusahaan Manufaktur yang Listing di BEI. Jurnal Mitra Ekonomi dan Manajemen Bisnis, Vol.1, Hal. 163-175.

Utari, Hilmi dan Ali Syaiful. (2008). Analisis Faktor-faktor yang Mempengaruhi Ketepatan Waktu Penyampaian Laporan Keuangan. Proceeding SNA XI. Pontianak.

Wijaya, M.S.V., \& Hadianto, B., (2008). Pengaruh Struktur Aktiva, Ukuran, Likuiditas, dan Profitabilitas Terhadap Struktur Modal Emiten Sektor Ritel di Bursa Efek Indonesia: Sebuah Pengujian Hipotesis Pecking Order. Jurnal Ilmiah Akuntansi, 7 (1): 71-84.

Zuhrotun, dan Zaki Baridwan.(2005). Pengaruh Pengumuman Peringkat terhadap Kinerja Obligasi. Simposium Nasional Akuntansi VIII. Solo. Hlm. 355. 